\title{
The role of leadership theory in raising the profile of women in management
}

\author{
Uma D. Jogulu and Glenice J. Wood \\ School of Business, University of Ballarat, Ballarat, Victoria, Australia
}

\begin{abstract}
Purpose To consider how leadership theories have helped or hindered raising the profile of women in management and leadership roles.

Design/methodology/approach This paper traces the earlier leadership theories through to the contemporary research on transactional and transformational leadership styles and offers a viewpoint on how each theory has contributed, or otherwise, to an awareness and acceptance of women in management and leadership roles.

Findings In 1990, research began to report gender differences in leadership styles with female managers being seen in positive terms as participative, democratic leaders. More recent work reports that women are believed to exhibit more transformational leadership style than their male colleagues, and this is equated with effective leadership.

Research limitations/implications All of the earlier theories on leadership excluded women and this exacerbated the problem of women not being seen as an appropriate fit in a management or leadership role. Recent findings clearly describe that the transformational qualities of leadership that women exhibit are required by the flatter organisational structures of today. Therefore, a more positive outcome for women advancing to senior roles of management or leadership may be observed in the future.

Originality/value The paper reviews the major leadership theories, and links these to a timeframe to illustrate how women were not visible in a management context until relatively recently. Such an omission may have contributed to the continuing low numbers of women who advance to senior management and leadership roles.
\end{abstract}

Keywords Leadership, Women, Careers

Paper type Conceptual paper

Early research by Burns (1978) concluded that "leadership is one of the most observed and least understood phenomena on earth" (Burns, 1978, p. 3). The quest to enhance our understanding of leadership has led to an enormous body of research and literature which has spanned centuries. This chapter will critically review the early theories of leadership through to current leadership research on transformational and transactional leadership styles, with a view to considering if previous theoretical approaches have played a role in raising the profile of women in management. It will also discuss how the current findings on leadership are likely to impact on the career advancement of women in leadership roles in the future.

\section{Leadership defined}

The word "leadership" was originally used in the early 1800s in writings about the political influence and control of the British Parliament during the first half of the 19th century (Bass, 1990). In this period, leadership was "based on inheritance, usurpation or appointment" and was considered to occur most frequently in Anglo-Saxon countries (Bass, 1990, p. 11). Early definitions of leadership recognised the importance of the ability to influence others, for example, "any act of influence on a matter of organizational relevance" (Katz and Kahn, 1966, p. 334). Tannenbaum et al. (1961) expanded on the importance of influence and defined leadership "as an interpersonal 
influence, exercised in situations and directed, through the communication process, toward the attainment of a specified goal or goals" (p. 24). As recently as 1990, Michener et al. (1990) described leadership "as a process that takes place in groups in which one member influences and controls the behaviour of the other members towards some common goal" (cited in Denmark, 1993, p. 343), suggesting that the control of employees was a necessary element of effective leadership.

However, more recently, the GLOBE Study of 62 societies has elaborated on this definition by describing leadership as "the ability of an individual to influence, motivate, and enable others to contribute toward the effectiveness and success of the organizations of which they are members" (House et al., 2004, p. 56). Here the focus extends beyond influence to include motivation and enabling of others to help achieve the goals of the organisation. Furthermore, the ability to control others is given no prominence in this recent definition of leadership. A brief review of early through to contemporary theories will be explored and consideration will be given as to the role each theory may have played in raising the profile of women in management or leadership roles.

\section{Early leadership theories}

In the 18th and 19th centuries, philosophers suggested a theory of leadership which was termed the "Great Man" theory (Denmark, 1993). This theory assumed that personal attributes of the great man "determined the course of history" (Denmark, 1993, p. 344). The great man was believed to have unique and exceptional features and qualities that distinguished him from his followers (Bass, 1990). Only very few people were thought to have such abilities, which were believed to be innate, i.e. leaders were born with these qualities (Denmark, 1993).

In this body of literature, women were not taken into account as possible leaders. The name given to encapsulate this theory illustrates that women were not perceived as leaders in any capacity at this time, and leadership research during this period related solely to males. Therefore, it is proposed that the Great Man theory cannot be claimed to have attributed anything towards raising the profile of women in management, as the theory was constructed as a male model at a time when women were not visible in paid employment.

One of the off shoots of the great man theory was a spawning of new research and theoretical propositions which focused on the traits or characteristics believed to distinguish leaders from non-leaders (Bass, 1990). The focus was on the unique and exceptional abilities and traits of certain individuals (Spotts, 1976). Trait theories were prominent in the literature from 1904 up to 1947 (Bass, 1990). Originally large lists of traits believed to be possessed by leaders were proposed in this theory (Spotts, 1976), however, the list was distilled to include self-confidence, need for achievement, the ability to have motives to carry out an action, and self-monitoring (Ellis, 1988). Once again, these traits were thought to be inborn, and unique to leaders.

Trait theories were fundamentally describing traits in masculine terms, and these characteristics were considered vital for successful leadership. In the 1900s, small numbers of women began to enter into the workforce with some women filling "helping roles" in organisations such as secretaries or assistants. However, only very small proportions of women took up management positions in the 1940s. For example, only 4 per cent of management roles were occupied by women in 1940 (Parker and Fagenson, 1994). More typically, women were seen as carers, assistants, teachers, or nurses rather than leaders during this period of time (see Koziara et al., 1987). 
Therefore, the caring and nurturing characteristics ascribed to females were not seen as appropriate in the role of leadership.

The importance bestowed on male characteristics or traits in leadership was confirmed in influential research which described the "think manager-think male" phenomenon (Schein, 1973). Schein's early research was carried out with male middleline managers in the USA, who reported that successful middle managers possessed attitudes, characteristics, and temperaments that were aligned to male rather than female characteristics. Therefore, it is reasonable to assume that there was no support drawn from the trait theories which would have had the effect of raising the profile of women in management. In fact, Schein's ongoing studies (Schein, 1973, 1975, 1992, 1994, 1996; Schein et al., 1989) have highlighted the pervasive perceptions that the "think manager-think male" attitudes continue to be found in many cultures, especially in male subjects. Strong managerial sex typing has been reported in British, Chinese, Japanese, German as well as US male management students, leading to this sobering observation: "Despite the many historical, political, and cultural differences that exist among these five countries, the view of women as less likely than men to possess requisite management characteristics is a commonly held belief among male management students around the world" (Schein, 2001, p. 683).

Soon after the 1940s, researchers began to propose that traits alone were not adequate to explain effective leadership, and that the interaction of leaders and followers, as well as other situational factors, may be a significant factor in effective leadership. At this stage, leaders were no longer considered to possess universal inborn characteristics and abilities (McGregor, 1976). Gardner (1989) proposed a new way of conceptualising leadership:

Many dismiss the subject with the confident assertion that "leaders are born not made." Nonsense! Most of what leaders have that enables them to lead is learned (Gardner, 1989, p. Xv).

This philosophy underpinned the birth of the behavioural theories of leadership in the 1930s and the perspective began to move from a belief in the inborn characteristics of leaders, to a focus on behaviour which could be acquired or learned.

There were four main behavioural studies. Firstly, the University of Iowa researchers isolated three behavioural dimensions; these were the democratic, autocratic, and laissez-faire styles (Lewin and Lippitt, 1938). Among these dimensions, the democratic style was believed to be most effective (Bass, 1990). Secondly, a study by Ohio State University in the 1940s and 1950s advanced this body of thought by dividing the behavioural theories into two dimensions which they termed "consideration" and "initiating structure" (Kerr et al., 1974). Consideration was explained as being considerate of followers' ideas and feelings. Initiating structure referred to structuring work relationship to meet job goals. The third study by the University of Michigan described "employee oriented" and "production oriented" dimensions (Kahn and Katz, 1960). The findings of the third study concluded that employee-oriented employers fostered high group productivity and job satisfaction amongst their employees (Kahn and Katz, 1960).

These concepts were extended in 1964, when Blake and Mouton proposed a Managerial Grid, using behavioural dimensions which included "concern for people" and "concern for production" as the two dimensions of assessing leadership behaviours (Blake and Mouton, 1964). The idea that there is one best leadership style was explored, and the researchers proposed that by incorporating the two dimensions of concern for 
people and concern for production the most effective way of leading could be achieved (Blake and Mouton, 1964). All these behavioural theories were proposed in the 1930s, but achieved prominence in the 1960s at a time when the number of women in positions of power or authority in organisations were still low.

In fact, the proportion of women in management roles in the USA in 1970, ten years after the behavioural theories reached their widest acceptance, was only 16 per cent. Furthermore, this percentage of women involved in a management role was reported to be constant for over a decade (Powell, 1999). Hence, the behavioural theories can be viewed as limited in raising the profile of women in management. However, during this period of research, there was an emerging recognition of the importance of a concern for people in the behavioural theories as being an effective leadership quality. A concern for people could be seen as a behaviour more typically associated with feminine characteristics.

Subsequently, the leadership literature moved on to embrace both individual traits and situational aspects of leadership simultaneously (Bass, 1990). Successful leadership was considered to be reliant on the leader's judgment and consideration of situational factors in order for an appropriate leadership style to be chosen to cope with each situation. Situational theories suggested that leadership is a matter of situational demands. Therefore, situational factors will play a role in determining who will emerge to take up a leadership role (Bass, 1990). Although situational leadership began to be studied in the 1930s, these theories did not achieve prominence until 1970 when empirical research was carried out focussing on the individual traits of a person as well as the situation the individual found themselves in (Hollander and Julian, 1970). These theories are also known as contingency theories of leadership.

This body of literature was published at a time when it was still uncommon for women to be in positions of management within organisations. As mentioned previously, Powell estimates that the proportion of women in management positions in the USA in the year 1970 was only 16 per cent (Powell, 1999) and, therefore, leadership roles for women were still unusual. When women were employed in organisations, they were more likely to be found in roles of support, rather than management positions which held any responsibility for leadership (Kanter, 1977).

Therefore, situational theories would have predominantly been seen as applying to males in management or leadership roles because of the low profile of women in management at this time, and it can be assumed that the profile of women in management would not have been advanced in any significant way from this body of literature.

Additional theories began to be published which focused on the specific leadership styles of leaders, in an attempt to increase understanding of what constituted effective leadership. These concepts relating to leadership styles were introduced in 1938 by Lewin and Lippitt, but reached prominence during the 1960s and 1970s. This body of research suggested that leaders vary in the way they led in organisations. Three styles of leadership were proposed.

Firstly, "autocratic leaders" were originally described as leaders who used their power to force, or their ability to persuade in leading their followers. A powerful autocratic leader influenced followers because of the power of the leader's position, or the power of the leader as a person made others expect that the leader would reward them for compliance or punish them for rejection (Bass, 1960, 1990). An autocratic leader was also defined as a person who used power to be strict rather than lenient, to supervise closely, and to ensure adherence to procedures (Blau and Scott, 1962). At the same time, an autocratic leader was also described as a directive leader. Traditionally 
in early studies these concepts described leadership as work related or person related behaviour which seemed to align with autocracy at one extreme end of the spectrum and democracy at another (Bass, 1990). As mentioned previously, very few women were occupying leadership roles during this period, and the autocratic style of leadership was not one which would have been associated with female gender stereotypical characteristics.

The second leadership style was termed "democratic leadership", which was explained as a style whereby the leader pursued an open, trusting, and followeroriented relationship. Leaders who adopted this style encouraged followers to establish their own policies, provided them with a perspective by explaining in advance the procedures for accomplishing the goals, and granted the followers independence to commence their own tasks and congratulating them in an objective manner. According to Bass (1990), this leadership style originated from America, and leaders adopting this style were described as caring, considerate, and easy to compromise and they also had a sense of responsibility and attachment to their followers.

This is the first body of research where it could be argued that the description of leadership, particularly in relation to the democratic style of leading was seen to be more favourably aligned to feminine characteristics as compared to masculine characteristics. However, as outlined previously, during the period when leadership style theories reached prominence, women were still not holding leadership positions in any significant numbers. As research on gender difference in leadership styles did not occur until 1990 (e.g. Eagly and Johnson, 1990), it would seem that the theories on leadership styles would have been written to describe male behaviour in leadership roles. Nevertheless, it could be argued that the theories on leadership styles began to raise the profile of women in management. This early leadership research may have changed perceptions about the suitability of women in management, as a democratic style of leadership could be attributed to both male and female managers.

A third leadership style was described as "laissez-faire" leadership. The term laissez-faire means to let others act without interference, and according to the early studies of Stogdill (1974) laissez-faire refers to the extent that leadership is either avoided or attempted (Bass, 1990). Laissez-faire leaders were thought to have less confidence in their supervisory duties, or in their capability to manage, often avoiding meeting with their subordinates (Bass, 1990). Similar to previous theories, this body of literature was studied in a male context, probably because of the small numbers of women in management roles at the time. Leadership was still seen as a male domain and this perspective is summed up by Bass as follows:

Democratic and authoritarian leadership was compared with laissez faire leadership by adults who were instructed how to lead boy's clubs (Bass, 1990, p. 545).

Hence, all of the above theories on leadership styles were achieving recognition as explanations to understand what constitutes effective leadership at a time when few women were in management positions or leadership roles. Leadership continued to be defined in male terms and was seen to be a natural "fit" for men. Thus in addition to earlier work on leadership theories, this body of literature on leadership styles does not appear to have raised the profile of women in management significantly.

In conclusion, the early leadership studies defined leadership in a male context. Recent research (Cames $e t$ al., 2001; Schein, 2001) provides us with an understanding of the pervasiveness of the belief that men, in particular, continue to view males, moreso than females, as more likely to possess the characteristics required to be an effective 
manager or leader. All of the theories reviewed depicted leadership implicitly or explicitly as a male prerogative, and the minimal numbers of women in management during the respective periods confirms that the role of management was largely seen as a male domain. These two factors could account for the lack of women or feminine characteristics being included in the leadership theories between 1940s and 1980s.

Not surprisingly, all the researchers and writers on early leadership were men and hence the years of leadership research reflect a male dominance. That is men practised leadership, and men wrote about it. The first edition of Stodgill's Handbook of Leadership in 1974 underscores this view. It ignored any gender theme in its review of leadership, and women were simply overlooked as having any potential as leaders.

Such an omission was recognised by Denmark (1993), who reflected that "by ignoring gender as a variable in studying leadership, researchers created many blanks in theoretical and research design" (Denmark, 1993, p. 345). However, gender began to be a consideration in the literature in the late 1970s. This gender difference research began to report on differences in behaviour, attitudes, and skills between males and females in general and was subsequently extended to consider abilities such as leadership.

\section{Gender difference theories}

As outlined in the previous section, all the early leadership studies developed theories which emanated from the Great Man theory. Thus, the theories described men and male leaders. This had the effect of excluding women from being seen in the role of a leader. At this time, men and women were considered to have very different behaviours, skills, and attitudes, and these "differences" were thought to handicap women in their career advancement (Morrison and Von Glinow, 1990).

In the 1970s, a literature on gender differences began to be published that set out to explore the extent of differences in men's and women's behaviour. This research into gender differences had at its base a desire to understand whether males and females differed on a variety of traits and behaviours because of their biological determination, the implication being that differences in behaviour between men and women are innate or acquired from very early socialisation. At this time, the perspective seemed to be that women were different to men and that difference appeared to be equated with deficiency (Fagenson, 1990).

The early work into gender differences by Maccoby and Jacklin (1974) focused mainly on children. Sex differences in various studies into social behaviour, cognition, and temperament were reviewed, and the conclusion was that there were very few sex differences between these groups. Similarities between the groups were found in many areas of functioning.

However, sex differences were reported in the following areas: girls were found to have greater verbal ability than boys, whereas boys were found to be superior in tasks requiring visual-spatial and mathematical ability. Furthermore, boys were found to be more aggressive, both physically and verbally. In addition, some findings were reported to be ambiguous; in areas of tactile sensitivity, fear and anxiety, levels of activity, competitiveness, dominance, compliance and maternal behaviour, the results were mixed.

In summary, this early work on gender differences reported both differences and similarities in the social behaviours, cognition, and temperament of the children in this meta-analytical study (Maccoby and Jacklin, 1974). It is interesting to note that the results of this review were widely reported as a finding of "no differences" in the behaviour of adults. However, more recent research into gender differences have 
reported that differences in behaviour, attitudes, and skills do exist in samples of adults, and that these differences may have implications for women and men at work.

Differences in the specific work-related behaviours, attitudes, and skills of men and women in management have been reported, particularly in the area of leadership. A large scale meta-analytical review of 162 studies on gender and leadership style compared the leadership styles of women and men and concluded that some differences existed. Eagly and Johnson (1990) found that male and female leaders performed similarly in both interpersonally oriented and task-oriented styles in studies conducted in organisations. That is, women were found to be equally capable of leading in a taskoriented fashion, and men were equally capable of leading in an interpersonal manner. However, women exhibited a more participative or democratic style, and men exhibited a more directive, autocratic style (Eagly and Johnson, 1990).

Following this work, a meta-analysis of 54 studies on gender and the emergence of leaders was conducted (Eagly and Karau, 1991). This review examined research on leader emergence in groups that were initially without a leader. Findings suggested that men emerged as task-oriented leaders more than did women, although such an event was most likely in short-term groups where the tasks set involved a relatively superficial level of social interaction. On the other hand, women were found to emerge as social leaders more frequently than men. That is, women engaged more often in leadership behaviour which showed agreement with other members and solidarity of views. Therefore, gender differences in leadership styles were proposed.

Eagly and Karau (1991) concluded that because of men's tendency to specialise in task-oriented behaviours, there is a socially accepted tendency for men to take up roles of leadership. It can be assumed that senior management roles would be seen as requiring task-oriented behaviour. According to Eagly and Karau (1991), "men's specialization relative to women in strictly task-oriented behaviors is one key to their emergence as group leaders" (p. 705). Thus, men were seen as a better fit than women in the role of leader.

In terms of gender differences in management capabilities, the attributes that could be presumed to impact on a manager's performance are primarily task-oriented leadership, and males were seen as exhibiting this style of leadership more than women. Therefore, the behaviours exhibited by males appear to equip them more comfortably to fill the role of manager, as it was defined at this time. According to Fielden and Davidson (1999), the "successful manager is aggressive, competitive, independent and self-reliant" (p. 74). Characteristics which include acting non-aggressively, being concerned for others welfare and having artistic qualities - attributes more readily associated with females are seen as "non-related management traits" (Orser, 1994, p. 11).

As can be seen from the above, the literature over the past three decades appears to have focused on what gender differences exist between males and females in general, as well as in terms of managerial qualities, including leadership abilities. The early research into gender differences underpinned a view that women were inappropriate in the role of management.

However, from the early 1990s, the literature began to tie together leadership styles with specific behaviours attributed to women. Not until this time was there a shift in the literature in terms of the valuing given to female characteristics in relation to leadership, such as the finding that women exhibited a more participative or democratic style in their leadership of others (e.g. Eagly and Johnson, 1990; Rosener, 1990).

As the proportion of women in management was increasing at this time (39 per cent in 1990: Powell, 1999), and women were achieving higher visibility, it is presumed that 
a greater recognition of women's characteristics and a greater valuing of what women could bring to a leadership role began to occur. Hence, the gender difference literature introduced a new perspective, as women were "seen" as managers and leaders, with different leadership styles to men, but nevertheless with qualities that were believed to be of benefit to employees, and that could "increase an organization's chances of surviving in an uncertain world” (Rosener, 1990, p. 120). Hence, the gender difference literature in this period could be seen as contributing towards women's career advancement in management. Women at last were visible in a management forum. The next section will further explore the recent theories of leadership, and evaluate if these make a further contribution to the recognition of the skills and attributes of women in management or leadership roles.

\section{Contemporary theories}

The beginning of the gender difference theories marked a shift in the leadership literature, as the behaviour, skills, and attitudes of women were considered, recognised, and evaluated. In turn, leadership styles were evaluated through the perspective of gender differences, and the focus began to shift to a desire to understand how men and women led their subordinates. This focus was made possible because of early work by Burns (1978) which described two very different types of leadership.

In the late 1970s, Burns developed a comprehensive theory to explain the differences between the behaviour of political leaders by using the terms "transactional" and "transformational" leadership. He defined transactional leaders as people who emphasized work standards, assignments and had task-oriented aims. Therefore, these leaders' focal points were believed to be on finishing tasks, with rewards or disciplining of followers intended to influence and improve employee performances (Burns, 1978).

In contrast, transformational leaders were defined as people who identified potential in their followers (Burns, 1978). Although no distinction was made between the leadership styles of men and women in this early research, Bass (1985) built on the early work of Burns and "opened opportunities for further investigations of the leadership styles of men and women” (see Eagly, 2003, p. 570). The adoption of the transactional and transformational leadership styles into contemporary leadership theory provided a platform for observing gender differences in leadership styles.

Bass and his colleagues described a transactional leadership style as one which utilised a transaction between leaders and followers, who were then rewarded or disciplined based on work performance (Bass and Avolio, 1994; Mandell and Pherwani, 2003). This style of leadership depends strongly on the leader's power to reinforce subordinates for their successful completion of tasks. Reinforcement can be materialistic or symbolic, immediate or delayed, partial or whole, and in terms of resources or rewards (Bass, 1997).

This transactional leadership style appears to characterise leadership in strong masculine qualities, as it is distinguished by "competitiveness, hierarchical authority and high control for the leader and analytical problem solving” (Klenke, 1993, p. 330) which is more typical of male behaviours. Of interest is the inclusion of "control" as a significant feature of the transactional style, common in definition of leadership in the 1990s.

In contrast, women generally fit into a "feminine model of leadership build around cooperation, collaboration, lower control for the leader and problem solving based on intuition and rationality" (Klenke, 1993, p. 330). This style of leadership is closely aligned to transformational leadership with effective leaders being described as those 
who inspired their followers and enabled them to achieve the goals set by the organisation (Bass, 1985).

In 1990, Bass (1990) extended this early work by adding that transformational leadership was "a behavioral process of being learned and managed. It's a leadership process that is systematic, consisting of purposeful and organized search for changes, systematic analysis, and the capacity to move resources from areas of lesser to greater productivity" (Bass, 1990, pp. 53-4). The leader achieves this stimulation by creating an awareness of the mission of the organisation and develops followers to a "higher level of ability and potential" (Mandell and Pherwani, 2003, p. 390). Additionally, transformational leaders were believed to have the ability to motivate, inspire, and support creativity in their followers. This appeared to be achieved through transformational leaders exhibiting a high degree of "individualized consideration", which is "the degree to which the leader attends to each follower's needs" and listens to their concerns by acting as a mentor (Judge and Piccolo, 2004, p. 755).

Transformational leadership theory was embraced further by management writers in the 1980s, as a way of effectively bringing about organisational changes (Avolio et al., 1991; Bennis and Nanus, 1985; Tichy and Devanna, 1986; Tichy and Ulrich, 1984). These researchers stressed that "transformational leaders help to realign the values and norms" (Avolio et al., 1991, p. 9) of an organisation to promote change. These values and norms are particularly valuable when an organisation encounters severe crises in motivating followers or in pursuing creative problem solving methods (Avolio et al., 1991).

Organisational change is achieved through transformational leaders creating an awareness of the goals and missions of the organisation, and according to Mandell and Pherwani (2003), this awareness enables followers to look beyond their own interests, which subsequently benefits the group and ultimately the organisation.

Transformational leadership to a large extent, therefore, characterises a feminine model of leadership, built around cooperation, lower levels of control, collaboration, and collective problem solving and decision-making. A recent empirical study of managers by Mandell and Pherwani (2003) confirms this summation, as it reports that females score higher on the transformational leadership scale compared to males (Mandell and Pherwani, 2003). Therefore, it is evident that women possess the qualities of a transformational leader, and it is these qualities that are believed to be required in today's organisations, which are flatter and less hierarchical in structure. Such organisations require more team work and consensus style of management (Wajcman, 1996). Women in management roles exhibit these "feminised leader behaviours" according to Omar and Davidson (2001, p. 40).

Therefore, a different style of leadership, built around characteristics such as caring, concern for others, and nurturing is required in contemporary organisations. This different style of leadership is the transformational style. Recent research concurs with this perspective and concludes that "women are better suited than men to serve as leaders in the ways required in the global economy" (Powell and Graves, 2003, p. 153).

These theories of transactional and transformational leadership marked the shift to a recognition of women in management and their feminine characteristics which were clearly acknowledged and valued. At the time these theories were achieving prominence, the numbers of women were also beginning to rise dramatically in management roles.

One significant finding that has arisen from the transactional and transformational theories of leadership is the suggestion that transformational leadership, more so than transactional leadership, is linked to leadership effectiveness: women managers, on 
average, tend to be more transformational and more proactive in addressing problems. As a consequence, they are likely to be seen as more effective and satisfying as leaders by both their male and female followers (Bass and Avolio, 1994). This finding is of great significance, as it is assumed that organisations would wish to capitalise on employees who exhibited the style of leadership which was most clearly aligned to leadership effectiveness.

\section{Leadership effectiveness}

Leadership effectiveness is defined as an "outcome of leaders' behaviour rather than a particular type of behaviour" (Eagly et al., 1995, p. 128). Leadership effectiveness is measured using numerous indicators such as followers' attitudes, level of commitment given to the organisation, and motivation towards the job (Howell and Costley, 2006).

Another indicator determining the effectiveness of leadership is the performance and outcomes of the organisation, or of group productivity (Eagly et al., 1995; Howell and Costley, 2006). Leaders are often perceived to be effective when an organisation achieves high profitability and productivity. This is especially true when the incident takes place after a particular leader commences his or her appointment. Additionally, lower employee turnover and absenteeism are also considered to be indicators of leadership effectiveness in an organisational setting (Howell and Costley, 2006).

At the individual level, one method of evaluation of leadership effectiveness requires rating "by subordinates, superiors and peers and leaders themselves" (Eagly et al., 1995). In terms of employee evaluation, transformational leaders are reported to be more satisfying and effective to work with compared to transactional leaders (Bass, 1997; Hater and Bass, 1988).

Therefore, there appears to be a strong correlation between transformational leadership and leader effectiveness, subordinate extra effort and subordinate satisfaction with the leader (Lowe et al., 1996; Seltzer and Bass, 1990). The results from numerous studies indicate that in terms of leadership effectiveness, the style of transformational leadership has been acknowledged to be one of the most effective way of leading people (Bass and Avolio, 1989; Burns, 1978; Tichy and Devanna, 1986). In addition, transformational leaders accomplish superior levels of success in the workplace as compared to transactional leaders, and are promoted more often, according to Bass (1997). More significantly, they are believed to produce better financial results than transactional leaders (Bass, 1997).

What is of interest is that the attributes of transformational leadership are closely aligned to feminine characteristics in general as compared to masculine characteristics. This may be because of the personal style of social interaction attributed to women: "women as a group compared to men are described as friendly, pleasant, interested in other people, expressive and socially sensitive" (Eagly and Johnson, 1990, p. 235). This creates an environment conducive of, and supportive to, work. Hence, higher job satisfaction of employees is likely to result in better attendance to work, low likelihood of leaving the organisation and fewer grievances (Howell and Costley, 2006).

The linking of effective leadership to transformational leadership has been confirmed in a recent meta-analysis of 45 studies by Eagly and her colleagues in 2003. These researchers concluded that "all of the aspects of leadership style on which women exceeded men relate positively to leaders' effectiveness whereas all of the aspects on which men exceeded women have negative or null relations to effectiveness" (Eagly et al., 2003, p. 569). That is, women were reported to demonstrate noticeably higher scores on all the subscales of transformational leadership and "contingent 
reward" subscale of transactional leadership as compared to men, who are reported to have considerably higher scores than women on "management by exception (active)", "management by exception (passive)" which are the subscales of transactional leadership and the Laissez-Faire scale (Eagly et al., 2003).

Therefore, according to these findings, women are more likely to possess leadership characteristics and attributes that are predominantly effective in contemporary circumstances compared with their male counterparts (Eagly et al., 2003). As such, these contemporary transformational and transactional leadership theories can be seen as playing a significant role in raising the profile of women in management and leadership roles, within an organisational context.

\section{Conclusion}

Today's organisations require more talented employees and these are increasingly found to be women (Burke and Cooper, 2004). In addition, the styles of leadership that are required are those that are more "relational-oriented, nurturing and caring" (Omar and Davidson, 2001, p. 40). Such styles are typically associated with women and are closely aligned with transformational leadership. This is a markedly different style of leadership from the "aggressive, competitive and task-oriented" styles, more readily associated with male managers (Omar and Davidson, 2001, p. 40). This new perspective has been termed the "feminisation of management" (Omar and Davidson, 2001) and is built on a recognition that women, while unique, are equally capable of making a valuable contribution towards the success of the organisation (Omar and Davidson, 2001)

However, despite these views and findings, the rarity of women in senior leadership roles continues to be documented worldwide. For example, according to a Catalyst report in 2003 in the USA, only 13.6 per cent of corporate board seats were held by women in the Fortune 500 companies at a time when 50.3 per cent of management, professional, and related occupations were held by women (Catalyst, 2003).

These figures, which are mirrored in other western countries, are alarming as they indicate that despite the fact that women are moving into management roles more readily, and more importantly, that they appear to possess the style of leadership which is closely aligned to effective leadership. Women are still not advancing into the more senior positions of leadership at the same rate as their male colleagues, even though they are recruited in similar numbers (Davidson and Burke, 2004).

These contemporary theories now include the behaviours, attitudes, and skills attributed to women in management roles. There is now a widely held recognition that women have what it takes to effectively lead in organisations today, and they are more likely to have these characteristics than are their male colleagues in management. Contemporary theories, therefore, have now made it possible to recognise the contribution that women can and do bring to a leadership role. It would seem, therefore, that although the leadership literature has played a significant role in raising the profile of women in management, further advances are required in order to advance the careers of women in management.

To date, these contemporary theories appear to have had little success in changing the attitudes of decision makers in organisations to appoint women more readily to leadership positions. It will be of great interest, therefore, to see if the recent findings of women's superiority in utilising effective leadership styles of interaction with their subordinates and organisational outcomes, actually translates into a dramatic increase in the numbers of women being appointed into senior leadership roles. After all, it is 
more than a decade ago that Bass and Avolio (1994) proposed that "women may make better managers". Despite this prediction, the increases of women in senior or executive roles over the past decade have been less than impressive. We must, therefore, ask the question: can leadership research and subsequent theories change perceptions of the appropriateness of women in management and leadership roles, or are the attitudes relating to the appropriateness of women in such roles still influencing organisational decision makers to overlook the potential offered by more than half of the management workforce?

\section{References}

Avolio, B., Waldman, D.A. and Yammarino, F.J. (1991), "Leading in the 1990s: the four I's of transformational leadership”, Journal of European Industrial Training, Vol. 15 No. 4, pp. 916.

Bass, B. (1960), Leadership, Psychology and Organizational Behaviour, Harper, New York, NY.

Bass, B. (1985), Leadership and Performance Beyond Expectations, Free Press, New York, NY.

Bass, B. (1990), Bass \& Stogdill's Handbook of Leadership: Theory Research and Managerial Applications, 3rd ed., Free Press, New York, NY.

Bass, B. (1997), "Does the transactional transformational leadership paradigm transcend organizational and national boundaries?", American Psychologist, Vol. 52 No. 2, pp. 1309.

Bass, B. and Avolio, B. (1989), Manual: The Multifactor Leadership Questionaire, Consulting Psychologist Press, Palo Alto, CA.

Bass, B. and Avolio, B. (1994), "Shatter the glass ceiling: woman may make better managers", Human Resource Management, Vol. 33 No. 4, pp. 54960.

Bennis, W. and Nanus, B. (1985), Leaders, Harper \& Row, New York, NY.

Blake, R.R. and Mouton, J.S. (1964), The Managerial Grid, Gulf, Houston, TX.

Blau, P.M. and Scott, W.R. (1962), Formal Organizations, Chandler, San Francisco, CA.

Burke, R.J. and Cooper, C.L. (2004), Leading in Turbulent Times: Managing in the New World of Work, Blackwell Publishing, Malden, MA.

Burns, J.M. (1978), Leadership, Harper Torchbooks, New York, NY.

Cames, I., Vinnicombe, S. and Singh, V. (2001), "Profiles of 'successful managers' held by male and female banking managers across Europe”, Women in Management Review, Vol. 16 No. 3, pp. 10817.

Catalyst (2003), Catalyst Census of Women Board Directors, available at: www.catalystwomen. org/about/mission.shtml (accessed 26 May 2005).

Davidson, M.J. and Burke, R.J. (2004), "Women in management worldwide: facts, figures and analysis an overview”, in Davidson, M.J. and Burke, R.J. (Eds), Women in Management Worldwide: Facts, Figures and Analysis, Ashgate Publishing Limited, Aldershot, pp. 115.

Denmark, F.L. (1993), "Women, leadership and empowerment”, Psychology of Women Quarterly, Vol. 17, pp. 34356.

Eagly, A.H., and Carli, L.L. (2003), The female leadership advantage: an evaluation of the evidence, The Leadership Quarterly, Vol. 14, pp. 80734.

Eagly, A.H. and Johnson, B.T. (1990), "Gender and leadership style: a meta analysis", Psychological Bulletin, Vol. 108 No. 2, pp. 23356.

Eagly, A.H. and Karau, S.J. (1991), "Gender and the emergence of leaders: a meta analysis", Journal of Personality and Social Psychology, Vol. 60 No. 5, pp. 685710. 
Eagly, A.H., Johannesen Schmidt, M.C. and Van Engen, M.L. (2003), "Transformational, transactional and Laissez Faire leadership styles: a meta analysis comparing women and men”, Psychological Bulletin, American Psychological Association, Vol. 129 No. 4, pp. 56991.

Eagly, A.H., Karau, S.J. and Makhijani, M.G. (1995), "Gender and effectiveness of leaders: a meta analysis”, Psychological Bulletin, Vol. 117 No. 1, pp. 12545.

Ellis, R.J. (1988), "Self monitoring and leadership emergence in groups", Personality and Social Psychology Bulletin, Vol. 14, pp. 68193.

Fagenson, E.A. (1990), "At the heart of women in management research: theoretical and methodological approaches and their biases”, Journal of Business Ethics, Vol. 9, pp. 26774.

Fielden, S.L. and Davidson, M.J. (1999), "Stress and unemployment: a comparative review and research model of female and male managers", British Journal of Management, Vol. 10, pp. 6393.

Gardner, J.W. (1989), On Leadership, Free Press, New York, NY.

Hater, J.J. and Bass, B. (1988), "Superior evaluations and subordinates' perceptions of transformational and transactional leadership", Journal of Applied Psychology, Vol. 73 No. 4, pp. 695702.

Hollander, E.P. and Julian, J.W. (1970), "Studies in leader legitimacy, influence, and innovation", Advances in Experimental Social Psychology, Vol. 5, pp. 3369.

House, R., Hanges, P., Javidan, M., Dorfman, P., and Gupta, V. (2004), Culture, Leadrship, and Organizations The GLOBE study of 62 Societies, Sage Publications Inc., Beverly Hills, CA.

Howell, J.P. and Costley, D.L. (2006), Understanding Behaviors for Effective Leadership, 2nd ed., Pearson Prentice Hall, Englewood Cliffs, NJ.

Judge, T.A. and Piccolo, R.F. (2004), "Transformational and transactional leadership: a meta analytic test of their relative validity", Journal of Applied Psychology, Vol. 89 No. 5, pp. 75568.

Kahn, R. and Katz, D. (1960), "Leadership practices in relation to productivity and morale", in Cartwright, D. and Zander, A. (Eds), Group Dynamics: Research and Theory, 2nd ed., Row Paterson, Elmsfort, NY.

Kanter, R. (1977), Men and Women of the Corporation, Basic Books, New York, NY.

Katz, D. and Kahn, R. (1966), The Social Psychology of Organizations, John Wiley and Sons, New York, NY.

Kerr, S., Schriesheim, C.J., Murphy, C.J. and Stogdill, R.M. (1974), "Toward a contingency theory of leadership based upon the consideration and initiating structure literature", Organization Behavior and Human Performance, Vol. 12, pp. 6282.

Klenke, K. (1993), "Meta analytic studies of leadership: added insights or added paradoxes?”, Current Psychology, Vol. 12 No. 4, p. 326.

Koziara, K.S., Moskow, M.H. and Tanner, L.D. (1987), Working Women Past, Present, Future, The Bureau of National Affairs, Inc., Washington, DC.

Lewin, K. and Lippitt, R. (1938), "An experimental approach to the study of autocracy and democracy: a preliminary note", Sociometry, Vol. 1.

Lowe, K.B., Kroeck, K.G. and Sivasubramaniam, N. (1996), "Effectiveness correlates of transformational and transactional leadership: a meta analytic review of the MLQ literature", The Leadership Quarterly, Vol. 7 No. 3, pp. 385426.

McGregor, D. (1976), An Analysis of Leadership, 2nd ed., University Associates, La Jolla, CA.

Maccoby, E.E. and Jacklin, C.N. (1974), The Psychology of Sex Differences, Stanford University Press, Stanford, CA.

Mandell, B. and Pherwani, S. (2003), "Relationship between emotional intelligence and transformational leadership styles: a gender comparison", Journal of Business and Psychology, Vol. 17 No. 3, pp. 387404. 
Michener, H.A., DeLamater, J.D., and Schwartz, S.H. (1990), Social Psychology, , 2nd ed., Harcourt Brace Jovanovich, Orlando, FL.

Morrison, A.M. and Von Glinow, M.A. (1990), "Women and minorities in management", American Psychologist, Vol. 45 No. 2, pp. 2008.

Omar, A. and Davidson, M.J. (2001), "Women in management: a comparative cross cultural overview”, International Journal of Cross Cultural Management, Vol. 8 No. 3/4, pp. 3567.

Orser, B. (1994), "Sex role stereotypes and requisite management characteristics: an international perspective”, Women in Management Review, Vol. 9 No. 4, pp. 1119.

Parker, B. and Fagenson, E.A. (1994), "An introductory overview of women in corporate management”, in Davidson, M.J. and Burke, R.J. (Eds), Women in Management: Current Research Issues, Paul Chapman, London.

Powell, G.N. (1999), "Reflections on the glass ceiling: recent trends and future prospects", in Powell, G.N. (Ed.), Handbook of Gender \& Work, Sage Publications, Newbury Park, CA, pp. 32545.

Powell, G.N. and Graves, L.M. (2003), "Leading People", Women and Men in Management, 3rd ed., Sage Publications, Newbury Park, CA, pp. 13356.

Rosener, J.B. (1990), “Ways women lead”, Harward Business Review, Vol. 68, pp. 11925.

Schein, V.E. (1973), "The relationship between sex roles streotypes and requisite management characteristics", Journal of Applied Psychology, Vol. 57 No. 2, pp. 95100.

Schein, V.E. (1975), "Relationship between sex role stereotypes and requisite management characteristics among female managers", Journal of Applied Psychology, Vol. 60 No. 3, pp. 3404.

Schein, V.E. (1992), "Sex role stereotyping and requisite management characteristics: a cross cultural look", Journal of Organizational Behavior, Vol. 13, pp. 43947.

Schein, V.E. (1994), "Managerial sex typing: a persistent \& pervasive barrier to women's opportunities", in Davidson, M.J. and Burke, R.J. (Eds), Women in Management: Current Research Issues, Paul Chapman, London, pp. 4152.

Schein, V.E. (1996), “Think manager think male: a global phenomenon”, Journal of Organizational Behavior, Vol. 17, pp. 3341.

Schein, V.E. (2001), "A global look at psychological barriers to women's progress in management", Journal of Social Issues, Vol. 57 No. 4, pp. 67588.

Schein, V.E., Mueller, R. and Jacobson, C. (1989), "The relationship between sex roles stereotypes and requisite management characteristics among college students”, Sex Roles, Vol. 20, pp. 10310.

Seltzer, J. and Bass, B. (1990), "Transformational leadership: beyond initiation and consideration”, Journal of Management, Vol. 16, pp. 693703.

Spotts, J.B. (1976), The Problem of Leadership: A Look at Some Recent Findings of Behavioral Science Research, 2nd ed., University Associates, La Jolla, CA.

Stogdill, R.M. (1974), Handbook of Leadership, 1st ed., Free Press, New York, NY.

Tannenbaum, R., Weschler, I.R. and Massarik, F. (1961), Leadership Organization: A Behavioral Approach, McGraw HIll, New York, NY.

Tichy, N.M. and Devanna, F. (1986), The Transformational Leader, John Wiley \& Sons, New York, NY.

Tichy, N.M. and Ulrich, D.O. (1984), "The leadership challenge a call for the transformational leader”, Sloan Management Review, Vol. 26 No. 1, pp. 5968.

Wajcman, J. (1996), “Desperately seeking differences: is management style gendered?", British Journal of Industrial Relations, Vol. 34 No. 3, pp. 33349. 